\title{
Uranium contamination of milk from cattle in the uranium-mining area in Siavonga District of Zambia: a preliminary human health risk assessment
}

Titus Haakonde ${ }^{1,2^{*}}$, John Yabe ${ }^{2,7}$, Kennedy Choongo ${ }^{3,8}$, Gershom Chongwe ${ }^{4,9}$, Gilbert Nchima ${ }^{5}$ and Md. Saiful Islam ${ }^{6}$

\begin{abstract}
Background: Contamination of cow milk with uranium $(U)$ is attracting global attention owing to U's radio-toxicity and chemical toxicity in humans and animals. Concentrations of $U$ in 223 cow milk samples from indigenous breeds reared in the proximity of a $U$ mine in Zambia were measured using the inductively coupled mass spectrometry, and the human health risks from exposure to $U$ through milk consumption were assessed.

Results: Milk from cattle reared in the U-mining area showed a significantly higher U-mean concentration $(0.83 \pm 0.64 \mu \mathrm{g} / \mathrm{L} ; t=9.95 ; \mathrm{ta}=0.05, p>0.05)$ than milk from cattle reared in the non-mining area $(0.08 \mu \mathrm{g} / \mathrm{L} \pm 0.05)$. Among the residents of the $\mathrm{U}$-mining area, the mean estimated daily intake (EDI), the target hazard quotients (THQs) and the target carcinogenic risks (TCRs) were all significantly $(p<0.05)$ elevated than among the residents of the nonmining area.

Conclusions: Since the EDIs, THQs and TCRs and the $U$ level in the cow milk were all within the World Health Organization's and the United States Environmental Protection Agency's permissible limits of $0.6 \mu \mathrm{g} / \mathrm{kg}-\mathrm{bw} /$ day $,<1,<10^{-4}$ and $30 \mu \mathrm{g} / \mathrm{L}$, respectively. The current study, therefore, has insufficient evidence to implicate $U$ exposure through consumption of cow milk in any non-carcinogenic or carcinogenic human health complications that are currently prevailing in the study area.
\end{abstract}

Graphic abstract: Keywords: Cow milk, Uranium contamination, Health impact, Zambia

\section{Background}

Exposure to heavy metals is one of the salient contributors to the non-communicable disease burden globally (ATSDR 2013; WHO 2018). Recent studies have reported considerable elevations in the levels of heavy metals such as lead $(\mathrm{Pb})$, arsenic $(\mathrm{As})$, cadmium $(\mathrm{Cd})$, mercury $(\mathrm{Hg})$ and uranium $(\mathrm{U})$ in the environment (Yabe et al. 2010;

\footnotetext{
*Correspondence: titusmog1@gmail.com

${ }^{1}$ Environmental Health Section, School of Applied and Health Sciences, Evelyn Hone College of Applied Arts and Commerce, Lusaka, Zambia Full list of author information is available at the end of the article
}

He et al. 2018). The presence of $U$, even in low concentrations, is valuable and may lead to metabolic disorders with severe consequences in animals and humans because of its chemical and radiotoxic properties (Katz 2014). Several studies have examined environmental exposure to $\mathrm{U}$ and its associated renal effects (VicenteVicente et al. 2010; Singh et al. 2013; Patočka 2014). As a chemical toxicant, $\mathrm{U}$ in its soluble form damages the kidneys at higher exposure doses and accumulates in kidney tissue and bones (ATSDR 2013). Some studies have equally revealed that both chronic exposure to low doses and acute exposure to high doses may result 
in neurotoxicity and genotoxicity in children and adults (Winde et al. 2019; Starościak and Rosiak 2015). Coincidentally, $\mathrm{U}$ in its insoluble form has been implicated in causing bone, lung and gastrointestinal cancer, as suggested by some studies (Bazyka et al. 2019; Boudebbouz et al. 2020). There is also increasing evidence suggesting that $\mathrm{U}$ exposure contributes to adverse birth and reproductive health outcomes in humans (Panikkar and Brugge 2007).

Human and animal exposure to $U$ occurs through inhalation, dermal contact and ingestion of contaminated soils, water or food grown in U-contaminated areas. Oral exposure to $U$ accounts for at least $90 \%$ of the overall exposure (Goussen et al. 2013). Therefore, contamination of the environment with $U$ raises critical health concerns, mainly as it may result in the accumulation of the element in many food items. Plants grown in contaminated environments may absorb $U$ from the soil (Anke et al. 2009), resulting in the exposure of livestock like cattle that graze on contaminated pasture and when fed on contaminated hay and forage (EFSA 2009). Furthermore, drinking water from sources contaminated with $\mathrm{U}$ can be another source of exposure for cattle (Fig. 1).

After ingestion, 95\% of the $\mathrm{U}$ is not absorbed into the body system and is eliminated via faeces (Mason and Moore 1982). Upon absorption, $\mathrm{U}$ is deposited in target organs such as the liver, heart, kidneys, brain and other systems in the body (Singh et al. 2013; He et al., 2018). The biological half-life of $U$ in the blood is 15 days, and its main route of excretion is the kidneys (ATSDR 2013).

Cow milk is widely used as a biomarker for monitoring exposure to toxic metals and deriving conclusions on the subsequent contamination of the food chain (Mitrović

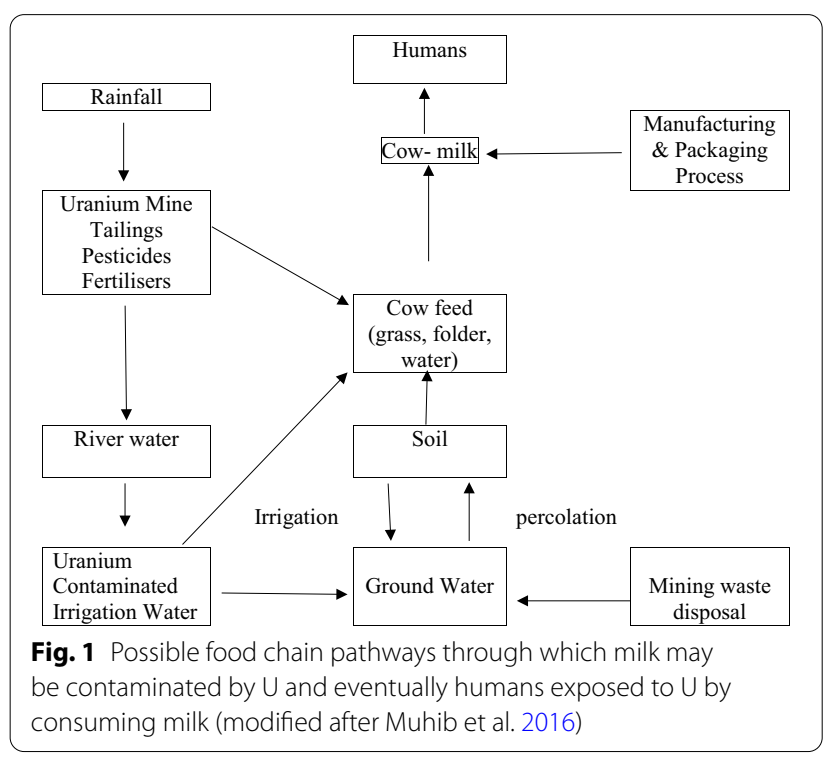

et al. 2020). The presence of $U$ and other heavy metals in cow milk has been reported in different countries (Qin et al. 2009; Meshref et al. 2014; Islam et al. 2017; Boudebbouz et al. 2020). Ingestion of pasture and water contaminated with $U$ by cattle, in turn, results in the contamination of the animal products such as beef and milk (Silanikove et al. 2010; Muhib et al. 2016; Ziarati et al. 2018), which may pose adverse health effects on the consumers of the so contaminated products. Studies in Navajo have shown evidence of transfer of $U$ in the food chain from soil to plants, to animals and then to man, and the study suggested that cow milk was a link of this $U$ transfer (Anke et al. 2009). In Serbia, Iran and Australia, significant positive correlations were observed between $\mathrm{U}$ levels in the soils sampled from grazing lands and the elevated U levels in the raw milk from cattle that grazed in such areas (Hashemi et al. 2017; Mitrović et al. 2016; Sandlos and Keeling 2016). Some health risk assessments studies have continued to suggest that consumption of cow milk contaminated with heavy metals (and $U$ is also a heavy metal) causes some non-communicable diseases such as cancers, cardiovascular-related complications and renal-related and respiratory-related health complications (Giri et al. 2011; Howard et al. 2017; Zehringer 2016).

However, it was observed that long-term exposure of consumers to heavy metal through consumption of cow milk gets less emphasis in developing countries, including in Zambia. To our knowledge, nothing is currently known about the levels of $U$ in cow milk except in drinking water in Zambia (Haakonde et al. 2020). Therefore, insight into $U$ uptake through cow milk and associated human health risks are still needed because cow milk contributes significantly to the diet of humans. Therefore, the present study was conducted to quantify the concentrations of $U$ in milk from indigenous cattle breeds reared in the U-mining area in Siavonga District of Zambia and to estimate further the human health risk of $U$ from consumption of milk.

\section{Methods \\ Study area and sampling locations}

The present study was conducted in Siavonga District in the Southern Province of Zambia. The study area is located at $16.53^{\circ}$ south latitude, $28.72^{\circ}$ east longitude and $511 \mathrm{~m}$ elevation above the sea level. Siavonga District occupies an area of about $2514 \mathrm{~km}^{2}$ and has a population density of 25.21 per $\mathrm{km}^{2}$. The current study focused on cattle from the villages in the Local Government Wards (LGW) in the U-mining area in Siavonga District in the Southern Province of Zambia. The mining area is surrounded by Nanyanga, Simamba, Sinadambwe and Manchahwa LGWs (Fig. 2). These study sites were selected 


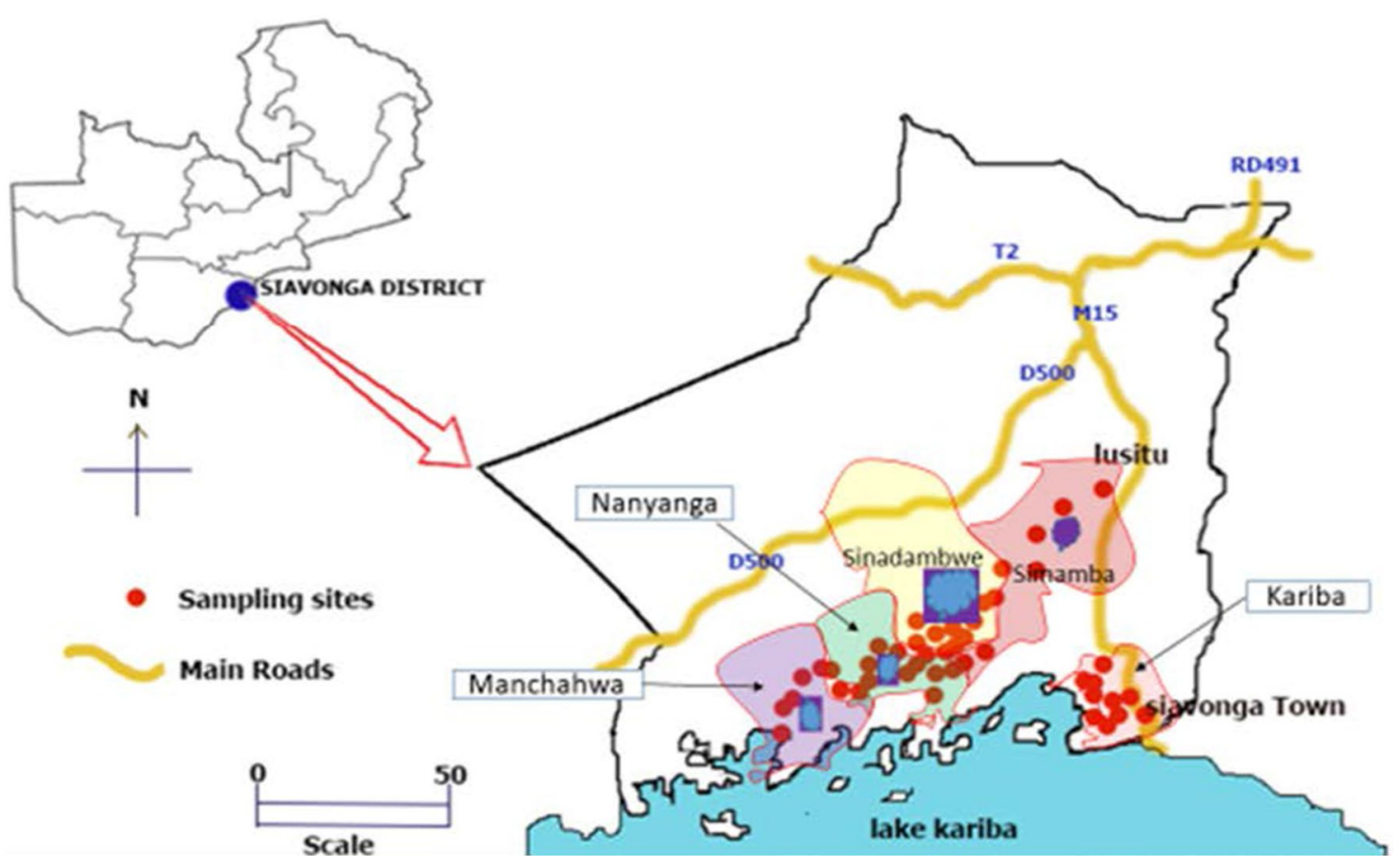

Fig. 2 Map of Siavonga District, Zambia, showing Manchahwa, Nanyanga, Sinadambwe, Simamba and Kariba Local Government Wards. The purple cloud-like shapes in squares show the uranium mining sites. Kariba ward does not have a uranium mining site as shown

because of $U$ mining (though the $U$ mining going on is undocumented) and exploration activities that have been ongoing since the late 1950s in the area (Randabel and Lusambo 2018; Van Aardt et al. 2018). For comparison purposes, Kariba LGW in Siavonga town, about $67 \mathrm{~km}$ away from the mining area and with no U-mining history, was also included in the study. The study area was predominantly inhabited by farmers engaged in crop and livestock farming. The indigenous Tonga cattle breed was reared in the study area through free-range open grazing method. However, there is a lack of documented studies about the geology and $U$ mining in the study area.

\section{Sample size}

The sample sizes for the two areas [U-mining area (exposed) and the non-mining area (non-exposed)] were calculated using Epi Info ${ }^{\text {TM7 }}$ (CDC, USA) statcalc for a cross-sectional study design (2 sided-confidence level $=95 \%$, power $=0.88$, odds ratio $=2.5$ and ratio of controls to cases $=2$ ). The desired sample size was 223 cows (mining area $n=100$ and non-mining area $n=123$ ) milk samples assuming random sampling. The grouping of cows into exposed and non-exposed groups was from the assumption that cows from the U-mining area are exposed to U. In contrast, cattle in the unexposed group were assumed to be not exposed to $U$.

\section{Sample collection}

The sampling activities were conducted between November 2019 and February 2020 (between the end of the dry season and rain season) to carter for seasonal variations. In each LGW, a raffle draw was conducted to randomly select the farmers who had lactating cows from which a milk sample was collected. From each sampled cow, a 50-mL milk sample was collected from the middle stream during the first milking of the day, after a thorough washing of the udder with water followed by double rinsing. All milk samples were stored in $50-\mathrm{mL}$ polypropylene bottles, pre-cleaned with $2 \% \mathrm{HNO}_{3}$ for $24 \mathrm{~h}$ and then double-rinsed with analytical grade Milli-Q water. The polypropylene bottles were kept sealed in cooler boxes and transported on dry ice to Zambia Agriculture Research Institute (ZARI) in the Soil Chemistry Laboratory for analysis.

\section{Sample preparation and $U$ extraction}

Uranium was extracted from cow milk samples using a method described by Yabe et al. (2018) with slight modifications. All the apparatus used in the extraction of $U$ was washed in $2 \% \mathrm{HNO}$, double-rinsed with Milli-Q water and oven-dried $\left(50{ }^{\circ} \mathrm{C}\right)$. A microwave digestion system (Berghof Microwave MWS-2, Germany) was used to extract $U$ from cow milk samples. Before sample 
digestion, cow milk samples were thawed. Briefly, $1 \mathrm{~mL}$ of each of the cow milk samples was placed in prewashed Teflon vessels. To these samples, $1 \mathrm{~mL}$ of $30 \% \mathrm{H}_{2} \mathrm{O}_{2}$ (Wako Chemical Co., Japan) and $5 \mathrm{~mL}$ of $60 \% \mathrm{HNO}_{3}$ acid (Kanto Chemical Co., Japan) were added. After digestion in the microwave for $52 \mathrm{~min}$ at temperature of up to $190{ }^{\circ} \mathrm{C}$, the digested samples were then transferred into $15-\mathrm{mL}$ polypropylene centrifuge tubes (Nalgene, New York), and the volume was brought to $10 \mathrm{~mL}$ with Milli-Q water.

\section{Metal analysis and quality control}

The concentrations of $U$ in cow milk samples were determined by inductively coupled plasma mass spectrometry (ICP-MS, Agilent 7700 Series, USA). Multi-element standard XSTC-13 (Spex-CertPrep ${ }^{\circledR}$, USA) (levels of $0,0.5,1,5,10,20,50$ and $100 \mu \mathrm{g} / \mathrm{L}$ of total $\mathrm{U}$ in $1 \mathrm{wt} \%$ $\mathrm{HNO}_{3}$ ) was used to prepare the calibration curve. The calibration curves with $r^{2}>0.90$ were accepted for concentration calculation. Stock solution (Agilent Technologies, USA) $50.0 \mu \mathrm{g} / \mathrm{L}$ was used as a tuning solution. All test batches were evaluated using an internal quality approach and validated for the defined internal quality controls (IQC). The standard reference material used in the current study was milk GBW (E) 07922 (National Research Centre for Standards, China). Reagent blanks and three analytical replicates were also used in each sample batch to ensure the accuracy and precision of the analysis. Good agreements were achieved between the data observed in the present study and the certified values, as shown in Table 1.

Cow milk samples were analysed for total $U$ with the ICP-MS operating at $\mathrm{m} / \mathrm{z}=238$ in normal mode. The standard operating conditions used were 1500-1550 WRF Power, $1.05 \mathrm{l} \mathrm{min}^{-1}$ carrier gas flow and $0.1 \mathrm{rps}$ per pump flow rate. The detection limit of the ICP-MS used in the present study was $0.003 \mu \mathrm{g} / \mathrm{L}$.

\section{Data Management and analysis}

\section{Uranium concentration in milk samples}

Sample analysis readings from the ICP-MS were coded and entered manually into the Microsoft Excel ${ }^{\circledR} 2016$ and standardized. The results were coded with the numbers 1 and 2 to represent the area from which each milk sample was collected (i.e. $1=$ from the mining area and $2=$ from the non-mining area) for each measured concentration of $U$ in a milk sample. Data were exported to SPSS (version 20, IBM Analytics, Armonk, NY) for preliminary analysis.

\section{Estimated daily intakes (EDIs)}

The estimated daily intake (EDI) of $U$ through milk consumption depends on: $\mathrm{Ci}=$ the median concentration of $\mathrm{U}$ in milk from the study sites, $\mathrm{D}=$ the approximate daily milk consumption rate and $\mathrm{BW}=$ the body weight $(70 \mathrm{~kg}$ for adults and $10 \mathrm{~kg}$ for children) of the individual milk and water consumer. The following formula was used to calculate EDI:

$$
\mathrm{EDI}=\frac{D \times C i}{\mathrm{BW}}
$$

where $D$ for milk was $21 \mathrm{~g} /$ day/person and $17 \mathrm{~g} /$ day/ person in adults and children, respectively, as the average consumption rates of cow milk, $\mathrm{Ci}(\mu \mathrm{g} / \mathrm{L})$ denotes $U$ concentration in milk and $\mathrm{BW}(\mathrm{kg})$ is the average body weight (Zambia Milk Consumption 1992-2007Knoema.Com, n.d; NSA 2018).

\section{Calculation of health risk}

Non-carcinogenic risk In the present study, the human health risks from $U$ due to its non-carcinogenic chemical toxicity from consumption of cow milk were determined based on the target hazard quotients (THQs) (dimensionless). The method of estimating health risk using THQs was described in the USEPA Region III risk-based concentration table (USEPA 2000). The equation for THQ is:

$$
\mathrm{THQ}=\frac{\mathrm{EFr} \times \mathrm{ED} \times \mathrm{EDI}}{\mathrm{RfD} \times \mathrm{AT}} \times 10^{-3}
$$

where EFr is the exposure frequency (365 days/year), $\mathrm{ED}$ is the exposure duration (64 years) equivalent to life expectancy in Zambia (NSA 2018) and EDI is determined by Eq. 1 . RfD is the oral reference dose for $\mathrm{U}(0.003 \mathrm{mg} /$

\begin{tabular}{|c|c|c|c|c|c|c|c|c|c|c|c|}
\hline \multicolumn{12}{|c|}{ Descriptive statistics } \\
\hline Variable & Site type & $n$ & Mean & Median & Tr. Mean & St. Dev & SE Mean & Min & Max & Q1 & Q3 \\
\hline \multirow[t]{2}{*}{ Conc. of $U$} & Mining area (case) & 100 & 0.83 & 0.83 & 0.76 & 0.64 & 0.06 & $\mathrm{BDL}$ & 3.62 & 0.43 & 1.03 \\
\hline & Non-mining area (control) & 123 & 0.08 & 0.08 & 0.08 & 0.05 & 0.004 & $\mathrm{BDL}$ & 0.24 & 0.05 & 0.11 \\
\hline
\end{tabular}

Table 1 Summary statistics for $U$ contamination in milk

Conc. $=$ Concentration in $\mu \mathrm{g} / \mathrm{L}$

Min, Max, Tr. Mean, St. Dev, SE Mean Q1 and Q3 stand for minimum, maximum, trimmed mean, standard deviation, standard error mean, lower quartile and the upper quartile, respectively

$B D L$ below detection limit of the ICP MS used in the analysis of the samples 
$\mathrm{kg} /$ day) as obtained from the Integrated Risk Information System (US-EPA 1999). AT is the averaging time for U's chemical toxicity (365 days/year $x$ number of exposure years, assuming 16 and 64 years are exposure years for children and adults, respectively). When $\mathrm{THQ}<1$, the chances of the exposed population to experience adverse health effects are unlikely as opposed to when THQ $\geq 1$, signifying that health risks in the exposed population are significant (USEPA 2010).

Target carcinogenic risk (TCR) The human health risks from $U$ due to its carcinogenic toxicity from consuming cow milk were determined based on the dimensionless target carcinogenic risk (TCR). The TCR factor (lifetime cancer risk) was also estimated using the equation provided in USEPA Region III risk-based concentration table (USEPA 2010):

$$
\mathrm{TCR}=\frac{\mathrm{EFr} \times \mathrm{ED} \times \mathrm{EDI} \times \mathrm{CSFo}}{\mathrm{AT}} \times 10^{-3}
$$

Here, $\quad E F r=$ exposure frequency $(365$ days/year $)$, $\mathrm{ED}=$ exposure duration (64 years for adults and 16 years for children) and the value for EDI is as determined by formula 1 . AT $=$ averaging time for carcinogens (365 days/year $\times 16$ years or 364 days/year $\times 64$ years). CSFo stands for oral carcinogenic slope factor of the intake dose conversion factor $\left(6.50 \times 10^{-8}\right)$ (USEPA 2010).

\section{Statistical analysis}

Data were statistically analysed using SPSS (version 20, IBM Analytics, Armonk, NY). Descriptive statistics of the samples were determined before the performance of a normality test using histograms and normal Q-Q plots. Data being normally distributed, the independent Student's $t$ test was used to compare means of U accumulation levels in milk from the different study sites. Cluster analysis based on Euclidean distance was used to determine accumulation patterns in different regions. The attribution of mining to $U$ contamination in cow milk samples concerning location was done through a dendrogram (not shown in the text due to size) using hierarchical cluster analysis, which was based on Euclidean distance intervals. Throughout the present study, a $p$-value of not more than 0.05 was considered to indicate statistical significance.

\section{Results}

Uranium concentration in cow milk

Cow milk from the U-mining area had higher concentrations of $U$ than cow milk from the non-mining areas (Table 1 and Fig. 3). More significant variations in the concentration levels of $U$ were observed in milk from catthe reared in the U-mining area compared with milk from the non-mining area. A statistical analysis by the independent Student's $t$ test showed that these differences in $\mathrm{U}$ concentrations and variations of the concentration levels of $U$ in milk from cattle reared in the $U$-mining area

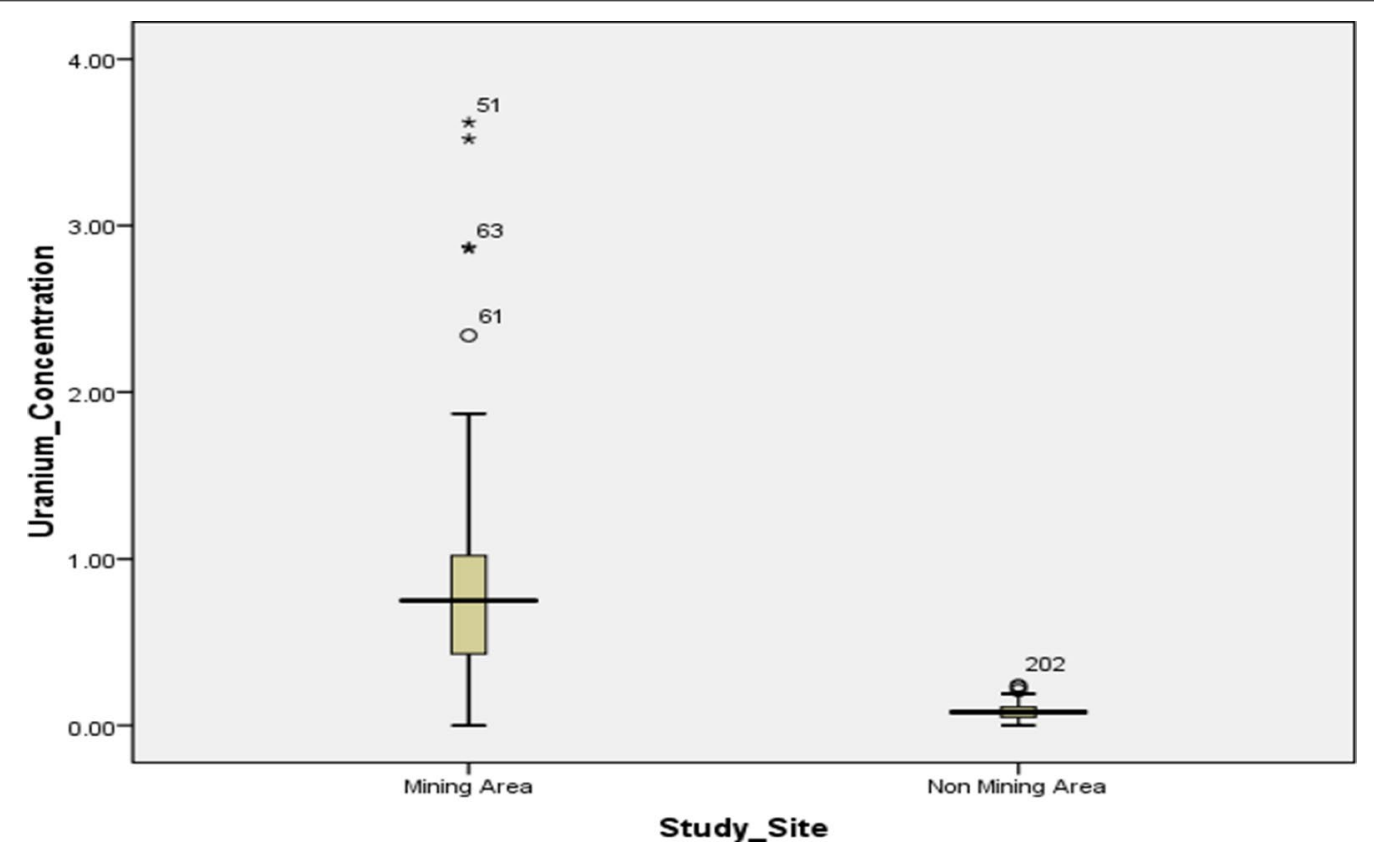

Fig. 3 Uranium concentrations levels in milk samples from the mining area and non-mining area 
and cattle reared in the non-mining area were statistically significant $[t=9.95 ; \mathrm{t} \alpha=0.05, p=0.006, \mathrm{CI}(0.64,0.87)]$. Additionally, the data demonstrated a $95 \%$ level of confidence that the mean U concentration levels in cow milk from the two sites differed by an amount between 0.64 and $0.87 \mu \mathrm{g} / \mathrm{L}$.

Uranium contamination levels in milk from cattle reared in the mining area and those reared far from the mining areas were depicted through a dendrogram by using the cluster method based on the Euclidian distance interval. A well-recognizable cluster for $U$ concentration levels in milk from cattle reared in the mining area was formed, unlike the uncoordinated cluster for milk from cattle reared away from the U-mining areas (Figure not shown).

\section{Dietary intake of $\mathrm{U}$ in Milk}

The EDIs of $U$ through consumption of cow milk by adults from the mining area and the non-mining area were $0.23 \mu \mathrm{g} / \mathrm{kg}$-bw/day and $0.02 \mu \mathrm{g} / \mathrm{kg}$-bw/day, respectively. The EDIs in children from the mining and the non-mining areas were $0.80 \mu \mathrm{g} / \mathrm{kg}$-bw/day and $0.09 \mu \mathrm{g} / \mathrm{kg}$-bw/day, respectively. Estimated daily intakes of $U$ through consumption of cow milk in both adults and children from the mining area were significantly $(p<0.05)$ elevated than in those from the mining area. All the EDIs of $U$ through cow milk consumption in the children and adults in the current study were below the USEPA maximum tolerable daily intakes (MTDIs) of $2.00 \mu \mathrm{g} / \mathrm{kg}$-bw/day, except for the children from the mining area whose EDI was below the WHO MTDI of $0.6 \mu \mathrm{g} / \mathrm{kg}$-bw/day (ATSDR 2010; WHO 2008) (Table 2).

\section{Health risk assessments}

The TCR and the THQ determined in the current study, as well as their established safe limits as given by the USEPA Region III risk-based concentration table (USEPA 2006), are shown in Table 2. The THQs of $U$ through consumption of milk were 0.08 and 0.27 among adults and children residing near the $U$ mine, respectively. Those residing in the non-mining area had THQs of 0.01 and 0.03 . The TCRs due to consumption of cow milk contaminated with $U$ were determined to be $1.5 \mathrm{E}-11$ and $5.2 \mathrm{E}-11$ among adults and children from the mining areas, respectively. Among adults and children residing in the non-mining areas, the TCRs were $1.3 \mathrm{E}-12$ and $5.85 \mathrm{E}-12$, respectively (Table 2 ).

The THQs and TCR for adults and children residing near the U-mining sites were significantly $(p<0.05)$ elevated than those for adults and children in the nonmining area. However, all the THQs and the TCRs were within the acceptable ranges recommended by USEPA and WHO (Table 2).

Table 2 Concentrations, cow milk estimated daily intakes, target hazard quotients and target carcinogenic risks of $U$ consumed by Zambian adults and children

\begin{tabular}{|c|c|c|c|c|c|c|c|c|}
\hline & \multirow[t]{2}{*}{$\begin{array}{l}\text { Sample } \\
(n=223)\end{array}$} & \multirow{2}{*}{$\begin{array}{l}\text { Concentration } \\
\text { of } \mathrm{U} \\
(\mu \mathrm{g} / \mathrm{L}) \pm \mathrm{SD}\end{array}$} & \multicolumn{2}{|c|}{$\begin{array}{l}\text { Estimated daily intake }(\mu \mathrm{g} / \\
\mathrm{kg}-\mathrm{bw} / \mathrm{day})\end{array}$} & \multicolumn{2}{|c|}{$\begin{array}{l}\text { Target hazard } \\
\text { quotient (THQ) }\end{array}$} & \multicolumn{2}{|c|}{ Target carcinogenic risk (TCR) } \\
\hline & & & $\begin{array}{l}\text { Adults (64 } \\
\text { years) }\end{array}$ & $\begin{array}{l}\text { Children } \\
\text { (16 years) }\end{array}$ & $\begin{array}{l}\text { Adults } \\
(64 \\
\text { years })\end{array}$ & $\begin{array}{l}\text { Children } \\
\text { (16 years) }\end{array}$ & Adults (64 years) & $\begin{array}{l}\text { Children (16 } \\
\text { years) }\end{array}$ \\
\hline $\begin{array}{l}\text { Case }(\cup \text { mine } \\
\text { area }^{\mathrm{a}}\end{array}$ & $n=100$ & $0.83 \pm 0.64$ & 0.23 & 0.80 & 0.08 & 0.27 & $1.5 \mathrm{E}-11$ & $5.2 \mathrm{E}-11$ \\
\hline $\begin{array}{l}\text { Control (about } \\
67 \mathrm{KM} \text { from } \mathrm{U} \\
\text { mine area) }\end{array}$ & $n=123$ & $0.08 \pm 0.05$ & 0.02 & 0.09 & 0.01 & 0.03 & $1.3 \mathrm{E}-12$ & $5.85 \mathrm{E}-12$ \\
\hline $\begin{array}{l}\text { Maximum } \\
\text { drinking water } \\
\text { limit }^{c}\end{array}$ & & 30 & & & & & & \\
\hline $\begin{array}{l}\text { Maximum } \\
\text { tolerable daily } \\
\text { intake (MTDI) }\end{array}$ & & & $2.00^{d}$ or $0.6^{e}$ & & & & & \\
\hline Risk safe limit ${ }^{f}$ & & & & & 1 & & $1.0 \mathrm{E}-6<\mathrm{TCR}<1.0 \mathrm{E}-4$ & \\
\hline
\end{tabular}

${ }^{a}$ Concentrations ranged from 0.00 to 3.62

${ }^{\mathrm{b}}$ Concentrations ranged from 0.00 to 0.24

cWHO (2011)

${ }^{d}$ WHO (2008)

e ATSDR (1999)

f USEPA (1989, 2010) 


\section{Discussion}

The present study revealed that the levels of $U$ were more elevated in milk from cattle reared in the U-mining area than in milk from cattle reared in the non-mining area. The differences in the contamination levels of cow milk with $\mathrm{U}$ could be attributed to the geological differences in the study areas coupled with U-mining and exploration activities that are prevailing. Van Aardt et al. (2018) indicated that $\mathrm{U}$ deposits in the mining area in Siavonga were found up to $123 \mathrm{~m}$ deep. Therefore, it is likely that $\mathrm{U}$ concentrations could either be naturally elevated, or the elevation could be from the anthropogenic activities emanating from the mining and explorations that have been ongoing since early 1960 in the study area (Randabel and Lusambo 2018). Evidence of deviations and elevations in $\mathrm{U}$ concentration levels in drinking water between the U-mining area and where there are no such U deposits in Siavonga exists (Haakonde et al. 2020). As such, the evidence of U-contamination of drinking water sources could also be extrapolated to the subsequent contamination of the surface soil and consequently the vegetation which cattle eat.

The feeding of cattle on vegetation and water allegedly contaminated with $U$ compromises the safety of the food chain and could result in humans being indirectly exposed to $U$ through consumption of beef and milk, mainly when sourced from near the U-mining area or from environments affected by mining activities (Stewart 2020). Navajo Nation, a United States Indian Reservation, has a record of elevated levels of $U$ and other heavy metals in milk and beef from cattle reared closer to an abandoned U mine (Arnold 2014). Similarly, the cluster analysis showed uniformity in $U$ contamination patterns in milk from cattle in the U-mining area (dendrogram not shown), probably suggesting that cattle were exposed to the common and similar sources of contamination in the current study area.

There is evidence associating the presence of residual $\mathrm{U}$ in animal products to animals consuming pasture and water from contaminated sources; currently, the evidence is limited to meat and milk (Štrok and Smodiš 2011; Muhib et al. 2016), but it is possible that further work will add $U$ exposure through consumption of such contaminated animal products to known health complications such as perturbed foetal growth, adverse birth outcomes, nephrotoxicity, hepatotoxicity, cognitive and behavioural disorders (Solderland et al. 2010; Samson et al. 2016; Ashrap et al. 2020).

The presence of $U$ in cow milk samples is not only a significant indicator that cows are exposed to $U$ but also food chain contamination (Zänker et al. 2019). Diet can be an important route of exposure to $U$ in humans, mainly through ingestion of locally grown foods or meat and meat products (in this case, cow milk) from animals reared near the mines or from the environment affected by mining operations (Patočka 2014; Stewart 2020). Estimated daily intakes of $U$ contaminants in a diet have been implicated in causing health effects. The toxicity of $\mathrm{U}$ depends on the dose typically determined by the sum of the EDIs of each food item an individual consumes. Using the USEPA risk deterministic method (Muhib et al. 2016), the EDIs of cow milk computed for individuals in the current study were considerably higher $(0.23 \mu \mathrm{g} /$ $\mathrm{kg}$-bw/day and $0.08 \mu \mathrm{g} / \mathrm{kg}$-bw/day) for consumers from the U-mining area than those from the non-mining area for both adults and children, respectively. Interestingly, children from the mining area had the EDI significantly higher than $0.6 \mu \mathrm{g} / \mathrm{kg}$-bw/day, which is the MTDI of U via food consumption (WHO 2018). Such a high EDI for children in the communities in the U-mining area is worrisome and indicates that the children were at risk of developing adverse health effects through consumption of milk sourced from the current study area. However, some studies have incriminated adverse health effects such as neurodevelopmental impairments, nephrotoxicity, hepatotoxicity, bone and lung cancers to $U$ exposure of individuals even to levels of $U$ lower than $30.00 \mu \mathrm{g} / \mathrm{L}$, a safe limit for $U$ in drinking water as well as the $0.6 \mu \mathrm{g} /$ kg-bw/day MTDI, respectively (Dublineau et al., 2014; Garboś and Święcicka 2015).

In the present study, the human health risks associated with the consumption of cow milk, based on THQs and TCRs, were generally negligible. Despite THQs from the current study being below the safety limit value $(\mathrm{THQ}<1)$, there is a possibility that the non-carcinogenic toxicity risk of $U$ from cow milk for the consumers could be elevated if other foods were to be considered in the health risk estimations ( $\mathrm{He}$ et al. 2018; $\mathrm{Hu}$ et al. 2019). The carcinogenic risk, expressed as TCR, is the estimated cumulative probability of an individual to develop cancer over a lifetime from chronic exposure to a potential carcinogen, in this case U (US-EPA 2010). In the current study, TCRs for adults and children in communities nearby to the U-mining area and the non-mining areas were below the safe of USEPA recommended safe limit of $10^{-4}$, despite being slightly elevated for communities in the U-mining area than in the non-mining area. The results of the current study based on the TCR values concur with the conclusions in the guidelines for Canadian Drinking Water Quality Technical Document (Canada Health 2020; Zamora 2010), indicating the lack of epidemiological evidence to implicate dietary ingestion of $U$ to causing cancer.

Though the potential health risk of the consumers to $\mathrm{U}$ exposure through cow milk consumption was low, it should not be ignored, especially in the U-mining area, 
given that dietary exposure to $\mathrm{U}$ is not solely through cow milk consumption (Rahman et al. 2014). The residents from the study area may be exposed to higher dietary $\mathrm{U}$ concentrations through consumption of cereals, vegetables, water, meat and meat products locally grown or reared in the study area. Such diets could directly increase the EDIs of U, subsequently increasing the THQs and the TCRs from negligible levels to within the acceptable range or to unacceptable limits (Howard et al. 2007). Food safety monitoring measures require to be strengthened in order to safeguard the contamination of the food chain with $\mathrm{U}$. As such, the present study is of great interest in terms of food safety, given that there is an absence of previous studies about the health impact of $U$ exposure at the national level in Zambia.

Studies of health risk assessments focussing on heavy metals other than $\mathrm{U}$ in different foodstuffs such as milk, cereals, meat and meat products, fish and vegetables have shown evidence of giving high THQs and TCRs due to the contributions made by different foodstuffs (Qin et al. 2009; Meshref et al. 2014). A similar effect in the study area would likely be observed if other food sources were considered.

Other studies that may determine the levels of natural $U$ and $U$ from mining activities (though the $U$ mining currently happening in the area is undocumented) so as to determine the effects which each one of them has on human health in the study area need to be conducted with urgency. This could help in reorienting the focus of any future environmental remediating or monitoring programmes to a true causer of the prevailing $U$ pollution currently alleged to be obtaining in Siavonga, Zambia.

\section{Conclusions}

The current study showed that U levels were elevated in milk from cattle reared in the U-mining area compared to milk from cattle reared in the non-mining area, suggesting that regional differences in the geology and the possible U-mining activities could be responsible for the U contamination of milk in the sampled cows in Siavonga, Zambia. The presence of residual $U$ in cow milk, if not routinely monitored in the U-mining area, could result in serious health complications among the milk consumers. We, therefore, recommend that further detailed studies be done to assess the levels of naturally occurring $U$ and $\mathrm{U}$ emanating from the mining and exploration activities so as to determine the effects which each of them could have on human health and the environment in the study area.
Abbreviations

WHO: World Health Organization; EDI: estimated daily intake; THQ: target hazard quotient; TCR: target carcinogenic risk; USEPA: United States Environmental Protection Agency.

\section{Acknowledgements}

The authors thankfully acknowledge the Ministry of Higher Education through the Department of Science and Technology for the support under the Science and Technology Postgraduate Scholarships. The authors are also delighted to express their gratefulness to the laboratory staff at Central Veterinary Research Institute in the Toxicology and Biochemistry Laboratory and the laboratory staff at Zambia Agricultural Research Institute for helping in quality control and protocols for the study to be successful.

\section{Authors' contributions}

$\mathrm{TH}$ and $\mathrm{JY}$ conceived and designed the study. TH and GN performed the experiments and analysed data. TH, JY, KC and GC interpreted the results and wrote the manuscript. MDSI reviewed the manuscript and provided scientific advice. All authors have read and approved the final manuscript.

\section{Funding}

The research was funded by the researchers only.

Availability of data and materials

All the data included in the current study are available.

\section{Declarations}

Ethics approval and consent to participate

Ethical clearance consistent was obtained from the Excellence in Research Ethics and Science (ERES) Converge, approval number "2019-Oct-015", and permission to conduct research approval was obtained from the National Health Research Authority.

\section{Consent for Publication}

Not applicable.

\section{Competing interests}

The authors declare no competing interest.

\section{Author details}

${ }^{1}$ Environmental Health Section, School of Applied and Health Sciences, Evelyn Hone College of Applied Arts and Commerce, Lusaka, Zambia. ${ }^{2}$ Department of Para-clinical Studies, School of Veterinary Medicine, The University of Zambia, Lusaka, Zambia. ${ }^{3}$ Department of Biomedical Sciences, School of Veterinary Medicine, The University of Zambia, Lusaka, Zambia. ${ }^{4}$ Department of Epidemiology and Biostatistics, School of Public Health, The University of Zambia, Lusaka, Zambia. ${ }^{5}$ Toxicology and Biochemistry Unit, Central Veterinary Research Institute, Ministry of Livestock and Fisheries, Balmoral, Chilanga, Zambia. ${ }^{6}$ Department of Soil Science, Patuakhali Science and Technology University, Dumki Patuakhali-8602, Bangladesh. ${ }^{7}$ Department of Pathobiology, Faculty of Agriculture and Natural Resources, School of Veterinary Medicine, University of Namibia, Windhoek, Namibia. ${ }^{8}$ College of Agriculture, Fisheries and Forestry, School of Veterinary Science and Animal Husbandry, Fiji National University, Koronivia Campus, Suva, Fiji Islands. ${ }^{9}$ Tropical Diseases Research Centre, Ndola, Zambia.

Received: 3 February 2021 Accepted: 12 May 2021

Published online: 22 May 2021

\section{References}

Agency for Toxic Substances and Disease Registry ATSDR (1999) Agency for toxic substances and disease registry. A toxicological profile for uUS Dept of Health and Human Services, Atlanta. Accessed at http://www.atsdr. cdc.gov/toxprofiles/tp150.pdf

Agency for Toxic Substances and Disease Registry ATSDR (2010) Agency for toxic substances and disease registry. A toxicological profile for 
uranium. US Dept of Health and Human Services, Atlanta Accessed at http://www.atsdr.cdc.gov/toxprofiles/tp150.pdf

Agency for Toxic Substances and Disease Registry [ATSDR] (2013) CB Search - Web Search. Agency Toxic Subst Dis Regist ATSDR 2013 - CB Search. Available: https://cbsearch.site/. Accessed 31 May 2020.

Anke M, Seeber O, Müller R et al (2009) Uranium transfer in the food chain from soil to plants, animals and man. Geochemistry 69:75-90

Arnold C (2014) Once upon a mine: the legacy of uranium on the Navajo Nation. Environ Health Perspect. https://doi.org/10.1289/ehp.122-A44

Ashrap P, Watkins DJ, Mukherjee B et al (2020) Predictors of urinary and blood Metal(loid) concentrations among pregnant women in Northern Puerto Rico. Environ Res 183:109178. https://doi.org/10.1016/j.envres.2020. 109178

Bazyka D, Gudzenko N, Dyagil I et al (2019) Cancers after Chornobyl: from epidemiology to molecular quantification. Cancers 11:1291. https://doi. org/10.3390/cancers11091291

Boudebbouz A, Boudalia S, Bousbia A, Habila S, Boussadia MI, Gueroui Y (2020) Heavy metals levels in raw cow milk and health risk assessment across the globe: a systematic review. Sci Total Environ 141830.

Canada Health. Guidelines for Canadian Drinking Water Quality Guideline Technical Document:Uranium.aem.Available:https://www.canada.ca/ en/healthcanada/services/publications/healthy-living/guidelines-canad ian-drinking-water-quality-guideline-technical-document-uranium.html. Accessed 31 May 2020. 2020.

Dublineau I, Souidi M, Gueguen Y et al (2014) Unexpected lack of deleterious effects of uranium on physiological systems following a chronic oral intake in adult rat. Biomed Res Int 2014:1-24. https://doi.org/10.1155/ 2014/181989

European Food Safety Authority (EFSA) (2009) Uranium in foodstuffs, in particular mineral water: Uranium in Food. EFSA J 7:1018. https://doi.org/ 10.2903/j.efsa.2009.1018

Garboś S, Święcicka D (2015) Application of bimodal distribution to the detection of changes in uranium concentration in drinking water collected by random daytime sampling method from a large water supply zone. Chemosphere 138:377-382

Giri S, Singh G, Jha VN, Tripathi RM (2011) Risk assessment due to ingestion of natural radionuclides and heavy metals in the milk samples: a case study from a proposed uranium mining area, Jharkhand. Environ Monit Assess 175:157-166

Goussen B, Parisot F, Beaudouin R et al (2013) Consequences of a multi-generation exposure to uranium on Caenorhabditis elegans life parameters and sensitivity. Ecotoxicology 22:869-878. https://doi.org/10.1007/ s10646-013-1078-5

Haakonde T, Yabe J, Choongo K et al (2020) Preliminary assessment of uranium contamination in drinking water sources near a uranium mine in the Siavonga District, Zambia, and Associated Health Risks. Mine Water Environ 39:735-745

Hashemi SE, Arfaeinia H, Ardashiri S, Karimyan K (2017) Health risk assessment of exposure to heavy metals in dairy products collected from Bushehr, Iran. Ann Trop Med Public Health 10:632

He L, Gao B, Luo X et al (2018) Health risk assessment of heavy metals in surface water near a uranium tailing Pond in Jiangxi Province, South China. Sustainability 10:1113. https://doi.org/10.3390/su10041113

Hinck JE, Linder G, Finger S et al (2018) Biological Pathways of Exposure and Ecotoxicity Values for Uranium and Associated Radionuclides. 72

Howard BJ, Beresford NA, Gashchak S et al (2007) The transfer of 239/240Pu to cow milk. J Environ Radioact 98:191-204

Howard BJ, Wells C, Barnett CL, Howard DC (2017) Improving the quantity, quality and transparency of data used to derive radionuclide transfer parameters for animal products. 2. Cow milk. J Environ Radioact $167: 254-268$

Hu Y, Zhou J, Du B et al (2019) Health risks to local residents from the exposure of heavy metals around the largest copper smelter in China. Ecotoxicol Environ Saf 171:329-336

Islam MS, Ahmed MK, Habibullah-Al-Mamun Md, Eaton DW (2017) Arsenic in the food chain and assessment of population health risks in Bangladesh. Environ Syst Decis 37:344-352. https://doi.org/10.1007/ s10669-017-9635-8

Katz S (2014) The Chemistry and Toxicology of Depleted Uranium. Toxics 2:50-78. https://doi.org/10.3390/toxics2010050
Meshref AMS, Moselhy WA, Hassan NE-HY (2014) Heavy metals and trace elements levels in milk and milk products. Food Measure 8:381-388. https:// doi.org/10.1007/s11694-014-9203-6

Mitrović B, Ajtić J, Lazić M et al (2016) Natural and anthropogenic radioactivity in the environment of Kopaonik mountain, Serbia. Environ Pollut 215:273-279

Mitrović BM, Vitorović O, Ajtić J, Vranješ B (2020) Radioactivity in the environment and food chain at mt. Maljen, Serbia. Roman Rep Phys 72:1-11

Muhib MI, Chowdhury MAZ, Easha NJ et al (2016) Investigation of heavy metal contents in Cow milk samples from area of Dhaka, Bangladesh. Food Contam 3:16. https://doi.org/10.1186/s40550-016-0039-1

National Statistical Agency (NSA) (2019) Zambia Demographic and Health Survey, Government Printers, Lusaka

Panikkar B, Brugge D (2007) The ethical issues in uranium mining research in the Navajo Nation. Accountab Res 14:121-153. https://doi.org/10.1080/ 08989620701290473

Patočka J (2014) Human health and environmental uranium. Military Med Sci Lett 83:120-131. https://doi.org/10.31482/mmsl.2014.022

Qin L-Q, Wang X-P, Li W et al (2009) The minerals and heavy metals in cow's milk from China and Japan. J Health Sci 55:300-305. https://doi.org/10. 1248/jhs.55.300

Rahman MS, Saha N, Molla AH (2014) Potential ecological risk assessment of heavy metal contamination in sediment and water body around Dhaka export processing zone, Bangladesh. Environ Earth Sci 71:2293-2308

Randabel J, Lusambo V (2018) The Karoo Sandstone-Hosted Uranium Deposit at Dibwe East, Mutanga, Zambia

Samson E, Piot I, Zhivin S et al (2016) Cancer and non-cancer mortality among French uranium cycle workers: the TRACY cohort. BMJ Open 6:e010316. https://doi.org/10.1136/bmjopen-2015010316

Sandlos J, Keeling A (2016) Aboriginal communities, traditional knowledge, and the environmental legacies of extractive development in Canada. Extract Ind Soc 3:278-287

Silanikove N, Leitner G, Merin U, Prosser CG (2010) Recent advances in exploiting goat's milk: quality, safety and production aspects. Small Rumin Res 89:110-124. https://doi.org/10.1016/j.smallrumres.2009.12.033

Singh L, Kumar R, Kumar S et al (2013) Health risk assessments due to uranium contamination of drinking water in Bathinda region, Punjab state, India. Radioprotection 48:191-202. https://doi.org/10.1051/radiopro/2012042

Stewart AG (2020) Mining is bad for health: a voyage of discovery. Environ Geochem Health 42:1153-1165. https://doi.org/10.1007/ s10653-019-00367-7

Štrok M, Smodiš B (2011) Natural radionuclides in milk from the vicinity of a former uranium mine. Nucl Eng Des 241:1277-1281

USEPA (1989) Integrated Risk Information System on Uranium, Soluble Salts. National Centre for Environmental Assessments, Office of Research and Development, Washington, DC

USEPA (1999) Integrated Risk Information System on Uranium, Soluble Salts. National Centre for Environmental Assessments, Office of Research and Development, Washington, DC

USEPA (2000) Integrated Risk Information System on Uranium, Soluble Salts. National Centre for Environmental Assessments, Office of Research and Development, Washington, DC

USEPA (2006) Regional Screening Levels (RSLs) - Generic Tables. US EPA. Available: https://www.epa.gov/risk/regional-screening-levels-rsls-generictab les. Accessed 31 May 2020

USEPA (2010) Integrated Risk Information System on Uranium, Soluble Salts. National Centre for Environmental Assessments, Office of Research and Development, Washington, DC

USEPA (2015) Regional Screening Levels (RSLS) - Generic Tables. US EPA. Available: https://www.epa.gov/risk/regional-screening-levels-rsls-gener ic-tables. Accessed 31 May 2020

Van Aardt J, Bowell R, BéruBé K, et al (2018) Geochemical and Bioreactivity Assessment of Future Mining Operations at Mutanga Uranium Project, Southern Province, Zambia

Vicente-Vicente L, Quiros Y, Pérez-Barriocanal F et al (2010) Nephrotoxicity of uranium: pathophysiological, diagnostic and therapeutic perspectives. Toxicol Sci 118:324-347. https://doi.org/10.1093/toxsci/kfq178

WHO (World Health Organization) (2008) Guidelines for drinking-water quality, vol.1, recommendations, 3rd edit, Geneva 
WHO (2011) Policies and procedures used in updating the WHO guidelines for drinking water quality. Public Health and the Environment World Health Organization Summit, Geneva

WHO (2018) Uranium in drinking water. Background document for development of WHO guidelines for drinking water quality. WHO/SDE/ WSH/03.04/118/Rev/1, Geneva

Winde F, Geipel G, Espina C, Schüz J (2019) Human exposure to uranium in South African gold mining areas using barber-based hair sampling. PLoS ONE 14:e0219059. https://doi.org/10.1371/journal.pone.0219059

Yabe J, Ishizuka M, Umemura T (2010) Current levels of heavy metal pollution in Africa. J Vet Med Sci 72:1257-1263

Yabe J, Nakayama SM, Ikenaka Y, Yohannes YB, Bortey-Sam N, Kabalo AN et al (2018) Lead and cadmium excretion in feces and urine of children from polluted townships near a lead-zinc mine in Kabwe, Zambia. Chemosphere 202:48-55

Zamora KC (2010) Uranium in drinking water: renal effects of long-term ingestion by an aboriginal community. Arch Environ Occup Health. https://doi. org/10.1080/19338240903241267
Zambia Milk consumption, 1992-2007 - knoema.com. Knoema. Available: https://knoema.com//atlas/Zambia/topics/Food-Security/Food-Consu mption/Milk-consumption. Accessed 18 May 2020.

Zänker H, Heine K, Weiss S et al (2019) Strong Uranium (VI) binding onto bovine milk proteins, selected protein sequences, and model peptides. Inorg Chem 58:4173-4189

Zehringer M (2016) Radioactivity in food: experiences of the food control authority of Basel-city since the Chernobyl Accident. In: Radiation Effects in Materials. IntechOpen, pp 132-160

Ziarati P, Shirkhan F, Mostafidi M, Zahedi MT (2018) An Overview of the Heavy Metal Contamination in Milk and Dairy Products. 14

\section{Publisher's Note}

Springer Nature remains neutral with regard to jurisdictional claims in published maps and institutional affiliations.

\section{Submit your manuscript to a SpringerOpen ${ }^{\circ}$ journal and benefit from:}

- Convenient online submission

- Rigorous peer review

- Open access: articles freely available online

- High visibility within the field

- Retaining the copyright to your article

Submit your next manuscript at $\boldsymbol{\nabla}$ springeropen.com 